\title{
STRATEGI PEMBERDAYAAN MASYARAKAT \\ MELALUI PENGEMBANGAN DESA WISATA DI DESA RAWABOGO KECAMATAN CIWIDEY KABUPATEN BANDUNG PROVINSI JAWA BARAT
}

\author{
Oleh \\ Agus Supriatna \\ Institut Pemerintahan Dalam Negeri \\ aguscaheum65@gmail.com
}

\begin{abstract}
$T$ This research focuses on the strategy of community empowerment through the Development of Rawabogo Tourism Village. The purpose of the study that the authors present is to analyze the inhibiting factors and to determine the efforts made in dealing with these inhibiting factors.

The method used by the writer is descriptive method with qualitative approach, technical data collection by observation, interview, and literature review analysis using SWOT analysis to look for strategies to be used. The results of the study, there are alternative strategies that can be implemented and recommended to the Regional Government of Bandung Regency and the Government of Rawabogo Village, namely: natural beauty, the appearance of arts and culture of the Rawabogo Village community. With the hope that the Bandung Regency Government will provide support for the empowerment of the people of Rawabogo Village and immediately issue a Decree of the Regent of Bandung regarding the designation of the Rawabogo Village as a Tourism Village.

The benefit of strenghtening human resources is by taking part in continuing education and training for the people of Rawabogo Village so that community empowerment is more optimal and community welfare is improved.
\end{abstract}

Keywords: community empowerment, tourism village development, and community welfare

\begin{abstract}
Abstrak
Denelitian ini mengambil fokus pada strategi pemberdayaan masyarakat melalui Pengembangan Desa Wisata Rawabogo. Tujuan penelitian yang penulis sajikan adalah untuk menganalisis faktor-faktor penghambatnya dan untuk mengetahui upaya yang dilakukan dalam menangani faktor-faktor penghambat.

Metode yang penulis digunakan, yaitu metode deskriptif dengan pendekatan kualitatif, teknis pengumpulan data dengan observasi, wawancara, dan analisis peninjauan literature dengan menggunakan analisis SWOT untuk mencari strategi yang akan digunakan. Hasil penelitian terdapat alternatif strategi agar dapat dilaksanakan dan direkomendasikan kepada Pemerintah Daerah Kabupaten Bandung maupun Pemerintah Desa Rawabogo, yaitu: keasrian alam, Penampilan kesenian dan kebudayaan masyarakat Desa Rawabogo. Dengan harapan Pemerintah Kabupaten Bandung agar memberikan dukungan terhadap pemberdayaan
\end{abstract}


masyarakat Desa Rawabogo dan segera menerbitkan Keputusan Bupati Bandung tentang penetapan Desa Rawabogo menjadi Desa Wisata.

Manfaat adanya penguatan sumber daya manusia dengan mengikuti Pendidikan dan Pelatihan yang berkelanjutan bagi masyarakat Desa Rawabogo agar pemberdayaan masyarakat lebih optimal dan peningkatan kesejahteraan masyarakat semakin meningkat.

Kata kunci: pemberdayaan masyarakat, pengembangan desa wisata, dan kesejahteraan masyarakat

\section{PENDAHULUAN}

U

ndang-Undang Nomor 23 Tahun 2014 tentang Pemerintahan Daerah Pasal 20 ayat (3) menyatakan bahwa: "urusan pemerintahan konkuren yang menjadi kewenangan daerah kabupaten/kota diselenggarakan sendiri oleh daerah kabupaten/kota atau dapat ditugaskan sebagian pelaksanaannya kepada desa".

Salah satupendukung dari pembangunan nasional adalah sumber daya dan kekayaan alam dalam hal ini salah satunya adalah bidang pariwisata yang dikelola langsung oleh pemerintah daerah. Indonesia memiliki potensi yang sangat besar dalam hal pariwisata, dengan adanya pariwisata Indonesia dapat meningkatkan devisa atau pendapatan negara untuk mewujudkan kesejahteraan rakyat. Hal ini tertuang dalam Undang-Undang Nomor 10 Tahun 2009 tentang Kepariwisataan yang menyatakan bahwa :"Pariwisata adalah berbagai macam kegiatan wisata yang didukung oleh berbagai fasilitas serta layanan yang disediakan oleh masyarakat, pengusaha, pemerintah, dan pemerintah daerah".

Otonomi Daerah diharapkan pemerintahan daerah dapat mandiri dalam mengelola semua potensi dan kekayaan yang ada di daerahnya sehingga dapat dioptimalkan menjadi salah satu cara yang menghasilkan sumber pendapatan dan pembiayaan kebutuhan daerah khususnya dalam pengembangan desa itu sendiri.

sebagaimana yang tercantum dalam potensi wilayah Kabupaten Bandung, salah satu menjadi modal utama untuk pemerintah daerah dalam mengembangkan wilayahnya yang berpotensi dalam rangka meningkatkan kesejahteraan masyarakat program pemberdayaan masyarakat. contoh tempat wisata di kabupaten Bandung yang sering menjadi tujuan wisata. Tempattempat wisata itu didukung dengan warisan budaya yang mencerminkan akan kaya kekayaan alam.

Provinsi Jawa Barat yang mempunyai potensiwilayahyangmenjadiperhatiandalam hal ini tempat-tempat wisata yang diminati oleh wisata domestik dan mancanegara yang saat ini sedang mengembangkan desa wisata sekaligus untuk memberdayakan masyarakat dalam rangka meningkatkan kesejahteraan masyarakat, seperti halnya Kabupaten Bandung yang merupakan salah satu kabupaten yang sedang berkembang di Provinsi Jawa Barat yang saat ini sedang Melakukan terobosan-terobosan dalam mengembangkan pemerintah yang ada dibawahnya, dalam hal ini, yaitu: pemerintahan desa untuk memberdayakan masyarakat dengan potensi wilayah yang dimilikinya,

Dukungan dari pemerintah untuk hal tersebut di atas Kementerian Pariwisata dan Ekonomi Kreatif mengalokasikan dana kepada Pemerintah Provinsi Jawa Barat Rp 5,3 miliar untuk pengembangan desa wisata. Dukungan dari Kementerian Pariwisata dan Ekonomi Kreatif pada Pemerintah Provinsi Jawa Barat ini dalam pengembangan desa wisata khususnya Kabupaten Bandung harus disambut baik untuk meningkatkan produktivitas dan kesejahteraan masyarakat.

Dalam Peraturan Menteri Kebudayaan dan Pariwisata Nomor :KM.18/HM.001/ MKP/2011 tentang pedoman Program 
Nasional Pemberdayaan Masyarakat (PNPM) Mandiri Pariwisata adalah suatu bentuk integrasi antara atraksi, akomodasi dan fasilitas pendukung yang disajikan dalam suatu struktur kehidupan masyarakat yang menyatu dengan tata cara dan tradisi yang berlaku.

Desa Wisata memiliki pengertian yang berbeda dengan desa maupun desa adat, desa adat belum tentu menjadi desa wisata begitu pula sebaliknya, desa wisata belum tentu berasal dari desa adat karena tidak semua desa adat dikomersialkan dalam bentuk kegiatan usaha pariwisata.Istilah desa adat dalam pengertian desa berbeda dengan desa wisata karena dalam UndangUndang Nomor 6 Tahun 2014 menyebutkan bahwa ketentuan desa adat adalah:

Kesatuan masyarakat hukum adat beserta hak tradisionalnya secara nyata masih hidup, baik yang bersifat teritorial, genealogis, maupun yang bersifat fungsional;

a. Kesatuan masyarakat hukum adat beserta hak tradisionalnya dipandang sesuai dengan perkembangan masyarakat; dan

b. Kesatuan masyarakat hukum adat beserta hak tradisionalnya sesuai dengan prinsip Negara Kesatuan Republik Indonesia.

Desa wisata menurut Wiendu (2011:23) adalah: "Suatu bentuk integrasi antara atraksi, akomodasi dan fasilitas pendukung yang disajikan dalam suatu struktur kehidupan masyarakat yang menyatu dengan tata cara dan tradisi yang berlaku. Atraksi adalah seluruh kehidupan keseharian penduduk setempat beserta setting fisik lokasi desa yang memungkinkan berintegrasi wisatawan sebagai partisipasi aktif seperti kursus tari, Bahasa dan lain-lain yang spesifik. Akomodasi adalah sebagian dari tempat tinggal penduduk setempat dan atau unit-unit yang berkembang atas konsep tempat tinggal penduduk."
Semenjak tahun 2014 salah satu program pemerintah dalam rangka mengembangkan pemerintahan desa agar dapat berkembang dan berdaya bagi masyarakatnya, yaitu Program PNPM Mandiri pariwisata yang menargetkan untuk pengembangan 2000 desa wisata melalui Program Nasional Pemberdayaan Masyarakat (PNPM) Mandiri.

\begin{tabular}{lll}
\multicolumn{1}{c}{ Pelaksanaan } & program & nasional \\
pemberdayaan masyarakat & tersebut \\
yang mengacu pada Peraturan & Menteri \\
Kebudayaan dan Pariwisata & Nomor: \\
KM.18/HM.001/MKP/2011 & tentang
\end{tabular}
Pedoman Program Nasional Pemberdayaan Masyarakat (PNPM) Mandiri Kementerian Pariwisata pada saat itu mengembangkan PNPM Mandiri Bidang Pariwisata dengan tujuan untuk meningkatkan kesejahteraan dan kesempatan kerja bagi masyarakat terutama masyarakat miskin melalui pengembangan desa wisata.

Perwujudan dari pemberdayaan masyarakat yang dilaksanakan melalui penyaluran bantuan dana desa wisata kepada kelompok masyarakat yang bersifat stimulan dan dirancang untuk memberi kesempatan berusaha dalam kegiatan kepariwisataan. Penggunaan dana bantuan desa wisata diprioritaskan pada kegiatan kolektif dan langsung menyentuh masyarakat miskin.

Di Kabupaten Bandung yang signifikan untuk meningkatkan Pendapatan Asli Daerah (PAD) adalah potensi pariwisata. Objek wisata yang terdapat di Kabupaten Bandung di antaranya adalah Glamping Lakeside Rancabali, Legok Kondang Legok Ciwidey, Taman Kelinci Ciwidey, Pemandian Air Panas Ciwalini, Barusen Hills Ciwidey, Situ Patenggang, Kampung Cai Ranca Upas, Kawah Putih, dan lain sebagainya. Kabupaten Bandung saat ini sedang memajukan desadesa yang berpotensi untuk menjadi desa wisata.

Menurut informasi yang penulis dapat dari Dinas Pariwisata dan Kebudayaan Kabupaten Bandung, bahwa tujuan dari 
menjadikan desa wisata adalah untuk meningkatkan kesejahteraan masyarakat, tetapi masih banyak masyarakat yang kurang memahami hal tersebut, sehingga tidak memanfaatkan adanya desa wisata tersebut. Akan tetapi pemerintah Kabupaten Bandung tidak menyerah untuk memberikan pengertian kepada masyarakat secara pelanpelan.

Dari 10 desa wisata objek wisata di Kabupaten Bandung salah satunya adalah Desa Wisata Rawabogo merupakan daerah persawahan dan perkebunan, mayoritas penduduk desa Rawabogo merupakan petani. Buruh Tani, Peternak, dll Desa Rawabogo, Kecamatan Ciwidey, Kabupaten Bandung, telah terpilih menjadi Desa Wisata.

Terpilihnya desa ini sebagai Desa Wisata bukanlah tanpa alasan. Setiap desa yang terpilih menjadi Desa Wisata tentu memiliki daya tarik wisata yang dapat mengundang wisatawan untuk datang ke desa tersebut. Desa Rawabogo Kecamatan Ciwidey Kabupaten Bandung. merupakan objek wisata yang menawarkan potensi wisata yang menonjolkan aktivitas beternak, bertani, dan pemandangan alam yang sangat indah dengan hamparan sawah yang luas, letaknya yang berada di lereng gunung dan diapit bukit serta suara aliran air sungai yang sangat jernih, dan perkebunan dengan pemandangan yang sangat indah.

Desa wisata Rawabogo, telah menyediakan resor atau hotel untuk menginap para wisatawan, dan ada juga tempat penginapan disediakan dirumah penduduk agar para wisatawan lebih mengenal budaya masyarakat setempat.

Dari hal tersebut, dengan menginap dirumah penduduk para wisatawan pun dapat melihat masyarakat dalam pengolahan hasil perkebunan, pertanian, dan peternakan. Keramahan masyarakat, kesenian yang dimiliki masyarakat membuat daya tarik tersendiri bagi wisatawan, kesenian budaya tersebut di antaranya adalah adanya
Kelompok Seni dan saung budaya Desa Rawabogo Kecamatan Ciwidey Kabupaten Bandung

Kesejahteraan masyarakat di Desa Rawabogo masih tergolong rendah. Dengan adanya Desa Wisata (Dewi) diharapkan mampu meningkatkan kesejahteraan masyarakat Desa Rawabogo, akan tetapi masih terdapat berbagai kendala yang dihadapi dalam pencapaian kesejahteraan tersebut.

Kelompok Sadar Wisata yang kepengurusannya belum tertata dengan baik, karena anggota Pokdarwis masih menjadikan itu sebagai hal sampingan, belum menjadikan suatu tujuan untuk membantu dan meningkatkan kesejahteraan masyarakat. Pemerintah Kabupaten Bandung masih belum optimal dalam membantu pembangunan sarana dan prasarana untuk mendukung daya Tarik wisatawan di lokasi wisata, contoh real pembangunan yang terjadi di sana, yaitu infrastruktur jalan menuju lokasi wisata yang masih jelek dan sempit. Sehingga banyak wisatawan yang menggunakan kendaraan beroda 4 sering kali berhimpit-himpitan dari arah yang berlawanan, belum lagi inisiatif dan partisipasi masyarakat dalam pembangunan jalan desa wisata masih sangat rendah yang menandakan bahwa masyarakat belum terlalu memahami pentingnya desa wisata guna membantu kesejahteraan masyarakat. Informasi tersebut penulis dapatkan dari Sekretaris Desa Rawabogo sebelum penulis melakukan penelitian secara langsung ke lapangan.

Berdasarkan penjelasan di atas, penulis merumuskan masalah sebagai berikut.

1. Bagaimana strategi pemberdayaan masyarakat melalui Desa WIsata dalam meningkatkan kesejahteraan masyarakat di Desa Rawabogo ?

2. Faktor-faktor apa saja yang menghambat strategi pemberdayaan masyarakat melalui Desa Wisata dalam meningkatkan 
kesejahteraan masyarakat di Desa Rawabogo ?

3. Bagaimana upaya yang dilakukan dalam menangani faktor penghambat strategi pemberdayaan masyarakat melalui Desa Wisata Rawabogo dalam rangka meningkatkan kesejahteraan masyarakat?

\section{TINJAUAN PUSTAKA}

\section{Strategi}

Definisi Strategi menurut Chandler dalam Rangkuti 2006:4 bahwa: "Strategi adalah tujuan jangka panjang serta pendayagunaan dan alokasi semua sumber daya yang penting untuk mencapai tujuan tersebut". Kemudian menurut Bintoro Tjokroamindjojo (1998:13) bahwa "Strategi merupakan "perhitungan" mengenai rangkaian kebijaksanaan dan langkahlangkah pelaksanaan

Selanjutnya Menurut Rangkuti (2008:6) menyatakan bahwa "Analisis SWOT adalah suatu proses kreatif dalam merencanakan strategi, kebijakan dan program-program kerja suatu organisasi atau unit organisasi, dengan memperhatikan situasi dan kondisi lingkungan internal dan eksternal, baik pada sisi positif maupun negatif. Dengan kata lain SWOT adalah identifikasi berbagai faktor secara sistematis untuk merumuskan strategi perusahaan dengan cara memaksimalkan kekuatan dan peluang, namun pada saat bersamaan dapat meminimalkan kelemahan dan ancaman. Sedangkan menurut Musa Hubeis dan Mukhamad Najib (2008:94-96) mengukur strategi dapat dilakukan dengan menggunakan analisis SWOT (Strength, Weakness, Opportunities, Threats) di mana strength, yaitu kekuatan, weakness, yaitu kelemahan, opportunities, yaitu peluang dan threats, yaitu ancaman. Dengan menggunakan analisis SWOT berbagai sudut pandang dalam melihat keterkaitan implikasi dari hubungan sehingga mudah menentukan suatu manufer, yaitu dengan mengaitkan analisis lingkungan internal dengan lingkungan eksternal terhadap strategi pemberdayaan masyarakat untuk meningkatkan kesejahteraan masyarakat melalui Desa Wisata. Terkait dengan analisis lingkungan tersebut, sebagaimana diungkapkan oleh Saleh (1999:47) bahwa:

Kedua jenis lingkungan internal dan eksternal ini secara impresif mempunyai pengaruh yang sangat kuat bagi keberlangsungan hidup suatu organisasi. Apabila sebuah organisasi tidak mampu membaca bahkan menguasai lingkungan maka eksistensi organisasi tersebut bisa terancam.

\section{Matriks SWOT}

\begin{tabular}{|c|c|c|}
\hline $\begin{array}{r}\text { Faktor } \\
\text { Internal }\end{array}$ & $\begin{array}{l}\text { STREGHTS } \\
\text { (S) / } \\
\text { Daftar } \\
\text { Kekuatan } \\
\text { Internal }\end{array}$ & $\begin{array}{l}\text { WEAKNESS } \\
\text { (W)/ } \\
\text { Daftar } \\
\text { Kelemahan } \\
\text { Internal }\end{array}$ \\
\hline $\begin{array}{l}\text { OPPORTUNI } \\
\text { TIES (O) } \\
\text { Daftar peluang } \\
\text { eksternal }\end{array}$ & $\begin{array}{l}\text { Startegi SO } \\
\text { Menggunakan } \\
\text { kekuatan } \\
\text { untuk } \\
\text { memanfaatkan } \\
\text { peluang }\end{array}$ & $\begin{array}{l}\text { Strategi WO } \\
\text { Meminimalkan } \\
\text { kelemahan } \\
\text { untuk } \\
\text { memanfaatkan } \\
\text { peluang }\end{array}$ \\
\hline $\begin{array}{l}\text { THREATHS } \\
\text { (T) } \\
\text { Daftar ancaman } \\
\text { eksternal }\end{array}$ & $\begin{array}{l}\text { Strategi ST } \\
\text { Menggunakan } \\
\text { kekuatan } \\
\text { untuk } \\
\text { mengatasi } \\
\text { ancaman }\end{array}$ & $\begin{array}{l}\text { Strategi WT } \\
\text { Meminimalkan } \\
\text { dan } \\
\text { menghindari } \\
\text { ancaman. }\end{array}$ \\
\hline
\end{tabular}

Sumber: Rangkuti (2014:83)

Untuk menentukan strateginya sebuah isu dapat menggunakan teknik "Litmus Test". Litmus Test merupakan suatu teknik yang digunakan untuk menentukan bagaimana strategisnya isu tersebut. Pada teknik ini setiap isu strategis yang sudah teridentifikasi diberikan sepuluh pertanyaan yang kemudian akan diberikan penilaiannya. Isu yang memiliki skor tertinggi merupakan isu yang benar-benar strategis dan isu yang 
memiliki skor terendah merupakan isu operasional.

Penentuan skor dari isu-isu tersebut sebagai berikut.

a) Skor 1 = untuk isu yang bersifat operasional.

b) Skor 2 = untuk isu yang cukup strategis.

cb) Skor 3 = untuk isu yang sangat strategis.

Dari hasil perkalian antara jumlah soal yang diperoleh nilai tertinggi 39 dan terendah 13. Sehingga diterapkan kategorisasi sebagai berikut.

a) Nilai $13-21=$ isu kurang strategis

b) Nilai 22-30 = isu cukup strategis

c) Nilai $31-39=$ isu sangat strategis

Suharto (2014:67) menyatakan bahwa pelaksanaan proses dan pencapaian tujuan pemberdayaan di atas dicapai melalui penerapan pendekatan pemberdayaan yang dapat disingkat menjadi 5P, yaitu:

Pemungkinan: menciptakan suasana atau iklim yang memungkinkan potensi masyarakat berkembang secara optimal. Pemberdayaan harus mampu membebaskan masyarakat dari sekat-sekat structural dan kultural yang menghambat.

1. Penguatan: memperkuat pengetahuan dan kemampuan yang dimiliki masyarakat dalam memecahkan masalah dan memenuhi kebutuhankebutuhannya. Pemberdayaan harus mampu menumbuhkembangkan segenap kemampuan dan kepercayaan diri masyarakat yang menunjang kemandirian mereka.

2. Perlindungan: melindungi masyarakat terutama kelompok lemah agar tidak tertindas oleh kelompok-kelompok kuat, menghindari persaingan yang tidak seimbang (apalagi tidak sehat) antara yang kuat dan lemah, dan mencegah terjadinya eksploitasi kelompok kuat terhadap kelompok lemah. Pemberdayaan harus diarahkan pada penghapusan segala jenis diskriminasi dan dominasi yang tidak menguntungkan masyarakat kecil.

3. Penyokongan: memberikan bimbingan dan dukungan agar masyarakat mampu menjalankan peranan dan tugastugas kehidupannya. Pemberdayaan harus mampu menyokong masyarakat agar tidak terjatuh ke dalam keadaan dan posisi yang semakin lemah dan terpinggirkan.

4. Pemeliharaan: memelihara kondisi yang kondusif agar tetap terjadi keseimbangan distribusi kekuasaan antara berbagai kelompok dalam masyarakat. Pemberdayaan harus mampu menjamin keselarasan dan keseimbangan yang memungkinkan setiap orang memperoleh kesempatan berusaha.

\section{Pemberdayaan Masyarakat}

Roesmidi (2006:11) menyatakan bahwa "secara etimologi kata pemberdayaan berasal dari kata daya yang artinya kekuatan, berdaya artinya bertenaga atau berkemampuan". Sedangkan menurut Sedarmayanti, 2014:286 "Pemberdayaan berasal dari kata empowerment, yaitu "sesuatu peningkatan kemampuan yang sesungguhnya potensinya ada, dan usahanya adalah dari kurang berdaya menjadi lebih berdaya".

Edi Suharto (2014:47) mengemukakan pengertian masyarakat adalah sekelompok orang yang memiliki perasaan sama atau menyatu satu sama lain karena mereka saling berbagi identitas, kepentingan-kepentingan yang sama, perasaan memiliki dan biasanya satu tempat yang sama".

Tikson (2001) mengemukakan bahwa dalam proses pemberdayaan masyarakat terdapat beberapa kegiatan yang sangat penting dan perlu dilakukan agar masyarakat memiliki kemampuan baik secara individual maupun secara bersama-sama dalam suatu 
organisasi menuju pada suatu kemandirian, yaitu:

\section{Capacity Building}

Yaitu kegiatan yang dilakukan untuk meningkatkan kemampuan masyarakat dalam hal keterampilan untuk bertindak dan bereaksi sesuai dengan situal riil pada lingkungan di mana mereka berada. Bidang ini berkenaan dengan pengembangan kapabilitas anggota masyarakat yang menyangkut aspek nilai-nilai dan budaya yang memiliki daya motivasi seperti semangat kerja sama dan gotong royong.Di samping itu, mereka juga harus mampu melawan berbagai ketertinggalan di dalam realitas sosial dan ekonomi mereka.

\section{Capacity Organizing,}

Yaitu kegiatan yang berkenaan dengan peningkatan partisipasi masyarakatyang dapat dilakukan secara efektif melalui pengorganisasian ke dalam beberapa bentuk sesuai dengan kebutuhan/ kepentingan lokal sebagai alat untuk menyatakan kehendak mereka dan untuk memengaruhi proses perubahan yang dikehendaki.

\section{Capacity Resources Management,}

Yaitu kegiatan yang dilakukan agar masyarakat mampu mengelola sumber daya dengan baik, termasuk di dalamnya penentuan varietas sumber daya yang potensial untuk dikembangkan dan yang terpenting adalah kemampuan dalam mengambil keputusan dan bertanggung jawab secara bersama-sama.

\section{Strategi Pemberdayaan Masyarakat}

Strategi pada dasarnya merupakan suatu alat atau cara untuk mencapai tujuan yang lebih baik. Dengan demikian strategi pemberdayaan masyarakat merupakan suatu alat atau cara untuk memberdayakan masyarakat.
I Nyoman Sumaryadi (2005:148149) menyatakan bahwa strategi program pengembangan masyarakat berorientasi pada pembangunan yang tercermin dalam empat generasi.

Generasi pertama mengutamakan relif and welfare, yaitu dengan berusaha segera memenuhi kekurangan atau kebutuhan makanan, kesehatan, dan pendidikan.

Generasi kedua memusatkan kegiatannya pada small-scale reliant local development atau disebut dengan community development, yang antara lain meliputi pelayanan kesehatan, penerapan teknologi tepat guna, dan pembangunan infrastruktur. Dalam hal ini, penyelesaian persoalan masyarakat bawah (grassroot) tidak dapat diselesaikan dengan pendekatan atas bawah (top-down approach), melainkan membutuhkan pendekatan bawah atas (bottom-up approach).

Kemudian, generasi ketiga adalah mereka yang terlibat dalam sustainable system development, mulai mempermasalahkan dampak pembangunan dan cenderung melihat jauh keluar daerahnya, ke tingkat regional, nasional dan internasional. Pada tahap ini terdapat usaha untuk memengaruhi perumusan kebijakan pembangunan. Strategi ini mengharapkan perubahan pada tingkat regional dan nasional.

Sedangkan strategi keempat merupakan fasilitator gerakan masyarakat (people's movement). Hal ini dilakukan dengan membantu rakyat mengorganisasi diri, mengidentifikasi kebutuhan lokal dan memobilisasi sumber daya yang ada pada mereka. Generasi ini tidak sekadar hanya memengaruhi perumusan kebijakan saja, tetapi mengharapkan adanya perubahan dalam pelaksanaannya.

Strategi pembangunan dari empat generasi ini kemudian harus dilengkapi dengan generasi kelima, yaitu pemberdayaan rakyat (empowering people). Pada era globalisasi dan perkembangan teknologi, 
masalah persaingan dan kerja sama menjadi isu penting. Generasi ini cenderung memperjuangkan ruang gerak yang lebih terbuka, dan untuk menciptakan pengakuan pemerintah terhadap arti penting inisiatif lokal.

\section{Desa Wisata}

Muljadi (2009:27), menjelaskan bahwa: "Desa Wisata sebagai suatu produk wisata yang melibatkan anggota masyarakat desa dengan segala perangkat yang dimilikinya". Desa wisata tidak hanya berpengaruh pada ekonominya, tetapi juga sekaligus dapat melestarikan lingkungan alam dan sosial budaya masyarakat terutama berkaitan dengan nilai-nilai kebersamaan, kekeluargaan, gotongroyong, dan lain-lain. Dengan demikian, kelestarian alam dan sosial budaya masyarakat akan menjadi daya tarik wisatawan yang melakukan perjalanan wisata.

Selanjutnya inskeep memaparkan pariwisata perdesaan sebagai suatu bentuk pariwisata, di mana wisatawan tinggal di desa tersebut, kebanyakan masih tradisional dan jauh dari keramaian, wisatawan belajar mengenai budaya hidup dan tradisi masyarakat setempat dan sering terlibat dalam aktivitas masyarakat setempat.

Chafid Fandeli,(2002:34) secara lebih komprehensif menempatkan desa wisata sebagai suatu wilayah perdesaan yang menawarkan keseluruhan suasana yang mencerminkan keaslian desa, baik dari segi kehidupan sosial budaya, adat istiadat, aktivitas keseharian, arsitektur bangunan, dan struktur tata ruang desa, serta potensi yang mampu dikembangkan sebagai daya Tarik wisata, misalnya atraksi, makanan dan minuman, cinderamata, penginapan, dan kebutuhan wisata lainnya.

\section{Kesejahteraan Masyarakat}

Kesejahteraan sosial memiliki beberapa makna yang relative berbeda, meskipun substansinya sama. Edi Suharto menjelaskan (2014:2) bahwa kesejahteraan sosial pada intinya mencakup tiga konsepsi, yaitu:

1. Kondisi kehidupan atau keadaan sejahtera, yakni terpenuhinya kebutuhan-kebutuhan jasmaniah, rohani, dan sosial.

2. Institusi, arena atau bidang kegiatan yang melibatkan lembaga kesejahteraan sosial dan berbagai profesi kemanusiaan yang menyelenggarakan usaha kesejahteraan sosial dan pelayanan sosial.

3. Aktivitas, yakni suatu kegiatan-kegiatan atau usaha yang terorganisir untuk mencapai kondisi sejahtera.

\section{METODE PENELITIAN}

Penelitian ini menggunakan metode deskriptif dengan pendekatan kualitatif. Menurut Nazir (2011:54) memberikan pengertian bahwa "Metode deskriptif adalah suatu metode dalam meneliti status sekelompok manusia, suatu objek, suatu kondisi, suatu sistem pemikiran, ataupun suatu kelas peristiwa pada masa sekarang". Tujuan dari penelitian deskriptif ini adalah untuk membuat deskripsi, gambaran atau lukisan secara sistematis, faktual dan akurat mengenai fakta-fakta, sifat-sifat serta hubungan antarfenomena yang diselidiki.

Selanjutnya Sugiyono memberikan pengertian tentang penelitian kualitatif di mana metode penelitian kualitatif adalah metode penelitian yang digunakan untuk meneliti pada kondisi objek yang alamiah, (sebagai lawannya adalah eksperimen) di mana peneliti adalah sebagai instrumen kunci, teknik pengumpulan data dilakukan secara triangulasi (gabungan), analisis data bersifat induktif/kualitatif, dan hasil penelitian kualitatif lebih menekankan makna dari pada generasi.

Penelitian ini berusaha memberikan gambaran terkait strategi pemberdayaan 
masyarakat melalui Desa Wisata Dalam Upaya meningkatkan kesejahteraan masyarakat Desa Rawabogo.

Teknik pengumpulan data yang digunakan adalah: wawancara, dokumentasi, dan observasi serta triangulasi. Sedangkan informan berjumlah dalam penelitian ini berjumlah 44 orang terdiri dari Kepala Dinas Kebudayaan dan Pariwisata Kabupaten Bandung, Kepala Desa Rawabogo, Sekretaris Desa Rawabogo, Ketua Kelompok Sadar Wisata, Masyarakat dan Wisatawan.

Teknik analisis data dalam penelitian ini, penulis menggunakan langkah-langkah analisis data menurut Miles dan Hubermen dalam Sugiyono, (2011:246), yaitu data reduction, data display, dan conclusion drawing/verification. Berdasarkan hasil penelitian akan ditemukan faktor penentu baik faktor penghambat atau faktor pendukung kemudian akan dianalisis menggunakan analisis SWOT Rangkuti (2006) sehingga menghasilkan strategistrategiuntukmenyusun upayayang mungkin digunakan untuk mengatasi hambatan dalam startegi pemberdayaan masyarakat melalui Desa Wisata Dalam Upaya Meningkatkan Kesejahteraan Masyarakat Desa Rawabogo.

\section{PEMBAHASAN}

\section{Startegi Pemberdayaan Masyarakat Melalui Pengembangan Desa Wisata}

Teori pemberdayaan menurut Suharto (2014:67) mengemukakan bahwa: pelaksanaan proses dan pencapaian tujuan pemberdayaan dicapai melalui penerapan pendekatan pemberdayaan yang dapat disingkat menjadi 5P, yaitu:

1. Pemungkinan: menciptakan suasana atau iklim yang memungkinkan potensi masyarakat berkembang secara optimal. Pemberdayaan harus mampu membebaskan masyarakat dari sekatsekat struktural dan kultural yang menghambat.
2. Penguatan: memperkuat pengetahuan dan kemampuan yang dimiliki masyarakat dalammemecahkanmasalahdanmemenuhi kebutuhan-kebutuhannya. Pemberdayaan harus mampu menumbuhkembangkan segenap kemampuan dan kepercayaan diri masyarakat yang menunjang kemandirian mereka.

3. Perlindungan: melindungi masyarakat terutama kelompok-kelompok lemah agar tidak tertindas oleh kelompokkelompok kuat, menghindari persaingan yang tidak seimbang (apalagi tidak sehat) antara yang kuat dan lemah, dan mencegah terjadinya eksploitasi kelompok kuat terhadap kelompok lemah. Pemberdayaan harus diarahkan pada penghapusan segala jenis diskriminasi dan dominasi yang tidak menguntungkan masyarakat kecil.

4. Penyokongan: memberikan bimbingan dan dukungan agar masyarakat mampu menjalankan peranan dan tugastugas kehidupannya. Pemberdayaan harus mampu menyokong masyarakat agar tidak terjatuh ke dalam keadaan dan posisi yang semakin lemah dan terpinggirkan.

5. Pemeliharaan: memelihara kondisi yang kondusif agar tetap terjadi keseimbangan distribusi kekuasaan antara berbagai kelompok dalam masyarakat. Pemberdayaan harus mampu menjamin keselarasan dan keseimbangan yang memungkinkan setiap orang memperoleh kesempatan berusaha.

Berdasarkan lima pendekatan tersebut, penulis melakukan wawancara guna mengetahui sejauh mana upaya-upaya yang telah dilakukan dalam upaya meningkatkan kesejahteraan masyarakat melalui desa wisata.

\section{- Pemungkinan}

Pemungkinan adalah tahapan dalam menciptakan suasana atau iklim yang 
memungkinkan potensi masyarakat berkembang secara optimal sehingga masyarakat terbebas dari sekat-sekat struktural dan kultural yang menghambat dalam upaya meningkatkan kesejahteraan masyarakat melalui Desa Wisata .

Berdasarkan wawancara penulis dengan Kepala Desa Rawabogo, Kusnadi pada 2 Agustus 2019 pukul 10.00 WIB bertempat di Ruang Kepala Desa Rawabogo, beliau menyampaikan bahwa, "Usaha wisata yang dilakukan di Desa Rawabogo sudah dimulai sejak tahun 2014 dengan warga masyarakat sudah memulai memproduksi suvenir, kerajinan tangan dan makanan khas untuk diasong di Desa Wisata dan Santosa Stable. "sehingga dapat disimpulkan bahwa usaha wisata di lingkungan masyarakat Desa Rawabogo sudah sekitar 2 tahun berjalan di mana masyarakat mulai memanfaatkan keahlian dan keterampilan untuk dijual di tampilkan.

Timbulnya semangat masyarakat Desa Rawabogo untuk bergelut di bidang usaha wisata dikarenakan lokasi desa tersebuttelah dijadikan Desa Wisata dan telah diresmikan langsung oleh Bupati Kabupaten Bandung. Pada akhirnya terbentuklah kelembagaan dari Dinas Kebudayaan dan Pariwisata Kabupaten Bandung, yaitu Kelompok Sadar Wisata, kelompok tersebut bertanggung jawab atas kemajuan Desa Wisata, dan juga terbitnya SK Desa Wisata pun tergantung kepada Pokdarwis.

\section{- Penguatan}

Penguatan merupakan usaha untuk memperkuat pengetahuan dan kemampuan yang dimiliki masyarakat dalam memecahkan masalah dan memenuhi kebutuhankebutuhannya serta menumbuhkembangkan segenap kemampuan dan kepercayaan diri masyarakat yang menunjang kemandirian dalam berusaha wisata.

Berdasarkan wawancara penulis dengan Kepala Dinas Pariwisata Kabupaten Bandung pada 3 Agustus 2019 pukul 09.30 WIB bertempat di ruang kerja beliau:Disbudpar Kabupaten Bandung membentuk Kelompok Sadar Wisata, kemudian melakukan pembinaan kepada kelompok tersebut, salah satu tujuannya adalah untuk meningkatkan kesejahteraan masyarakat di Desa Rawabogo melalui Desa Wisata, Disbudpar juga telah menyelenggarakan beberapa kegiatan diklat guna mendukung pengembangan Desa Wisata tersebut sehingga dapat membantu perekonomian masyarakat setempat. Salah satunya juga perwakilan dari Dinas Pariwisata Kabupaten Bandung sering meninjau Desa Wisata tersebut dan memberikan penyuluhan untuk mengembangkan desa tersebut, antara lain dengan cara mengembangkan home stay, kerajinan tangan dan juga makanan khas yang dimiliki Desa Rawabogo. Pemerintah juga memberikan kesempatan seluas-luasnya kepada Desa untuk mengembangkan Desa Wisata tersebut. Pokdarwis tersebut juga memuat Kelompok Wanita Tani (KWT), karena Desa Wisata menonjolkan dalam bidang Bertani.

Berdasarkan pernyataan di atas, dapat disimpulkan bahwa sudah ada upaya dalam penguatan pengetahuan dan kemampuan masyarakat dalam rangka meningkatkan kesejahteraan masyarakat melalui Desa Wisata oleh Pemerintah daerah, yaitu Dinas Kebudayaan dan Pariwisata. Akan tetapi masih terdapat keluhan dari masyarakat Desa Rawabogo seperti yang disampaikan oleh Sekretaris Desa Rawabogo Ibu Siti Mahmudah dalam kesempatan wawancara dengan penulis pada 4 Agustus 2019 pukul 08.30 WIB.

Dalam setiap penyuluhan yang diselenggarakan oleh instansi-instansi terkait mengenai desa wisata tersebut, pada akhirnya tidak berkelanjutan dan tidak maksimal dalam penyelenggaraannya karena instansiinstansi tersebut tidak secara optimal membantu masyarakat. Bahkan sempat mendatangkan Mahasiswa dari Sekolah 
Pariwisata untuk magang di Desa Wisata tersebut tapi hasilnyapun tidak optimal.

\section{- Perlindungan}

Perlindungan dalam hal ini adalah upaya untuk melindungi masyarakat terutama kelompok-kelompok lemah agar tidak tertindas oleh kelompok-kelompok kuat atau dengan kata lain adalah upaya penghapusan segala jenis diskriminasi dan dominasi yang tidak menguntungkan masyarakat kecil.

Dinas Kebudayaan dan Pariwisata Kabupaten Bandung telah membentuk Kelompok Sadar Wisata yang diharapkan mampu menjadi wadah yang salah satu fungsinya adalah sebagai fungsi perlindungan seperti yang dijelaskan di atas, akan tetapi belum adanya kesamaan persepsi antara Pokdarwis dengan masyarakat dalam mengelola Desa Rawabogo menyebabkan sampai saat ini fungsi Pokdarwis belum terlaksana secara maksimal, hal tersebut sesuai dengan penyampaian Ketua Pokdarwis, Bapak Agung dalam kesempatan Wawancara dengan penulis pada 4 Agustus 2019 pukul 13.00 WIB bertempat di kediaman beliau bahwa:

Pokdarwis diharapkan mampu menjadi wadah untuk masyarakat pelaku usaha wisatagunameningkatkan kesejahteraan masyarakat melalui desa wisata tersebut akan tetapi belum adanya kesepahaman antara desa dan masyarakat menjadikan fungsi Pokdarwis belum maksimal karena masyarakat berpikir bahwa Pokdarwis hanya akan mengurangi jumlah pendapatannya.

Berdasarkan penjelasan tersebut, dapat disimpulkan bahwa sudah ada upaya dalam melindungi kelompok-kelompok kecil agar tidak ada diskriminasi dan dominasi oleh kelompok-kelompok kuat, yaitu dengan dibentuknya Pokdarwis, akan tetapi fungsi Pokdarwis yang belum maksimal membuat belum ada jaminan atas perlindungan tersebut karena anggota dari Pokdarwis pun belum maksimal dalam menjalankan tanggung jawabnya.

\section{- Penyokongan}

Penyokongan merupakan upaya untuk memberikan bimbingan dan dukungan agar masyarakat mampu menjalankan peranan dan tugas dalam perannya masing-masing.

Berdasarkan wawancara penulis dengan Kepala Dinas Kebudayaan dan Pariwisata Kabupaten Bandung pada hari Selasa, 3 Agustus 2019 pukul 09.30 WIB bertempat di ruang kerja beliau:

Disbudpar dalam upaya pengembangan desa wisata, khususnya Desa Rawabogo telah membentuk Kelompok Sadar Wisata dan telah memberikan pelatihan serta Pembinaan kepada Anggota Kelompok Sadar Wisata guna mendukung peningkatan kesejahteraan masyarakat melalui Desa Wisata antara lain diklat homestay, pelatihan keterampilan membatik dan pelatihan membuat website.

Berdasarkan hasil wawancara tersebut, dapat disimpulkan bahwa sudah ada usaha dari Pemerintah Daerah untuk menyokong masyarakat agar memiliki keterampilan untuk memajukan Desa Wisata dan akhirnya dapat membantu meningkatkan kesejahteraan masyarakat tersebut.

\section{- Pemeliharaan}

Pemeliharaan dalam hal ini adalah upaya untuk memelihara kondisi agar tetap terjadi keseimbangan dan keselarasan yang memungkinkan setiap orang untuk memperoleh kesempatan berusaha.

Desa Rawabogo seperti apa yang dijelaskan pada pendekatan sebelumnya telah membentuk Kelompok Sadar Wisata yang diharapkan mampu menjadi wadah yang salah satu fungsinya adalah sebagai fungsi pemeliharaan seperti yang dijelaskan di atas, akan tetapi belum adanya kesamaan persepsi antara Pokdarwis dengan masyarakat dalam 
mengelola Desa Rawabogo menyebabkan sampai saat ini fungsi Pokdarwis belum terlaksana secara maksimal, hal tersebut sesuai dengan penyampaian Ketua Pokdarwis, Bapak Agung dalam kesempatan wawancara dengan penulis pada 4 Agustus 2019 pukul 13.00 WIB di kediaman beliau bahwa:

Pokdarwis diharapkan mampu menjadi wadah untuk masyarakat pelaku usaha wisatagunameningkatkankesejahteraan masyarakat melalui desa wisata akan tetapi belum adanya kesepahaman antara desa dan masyarakat menjadikan fungsi Pokdarwis belum maksimal karena masyarakat berpikir bahwa Pokdarwis hanya akan mengurangi jumlah pendapatannya.

Berdasarkan wawancara penulis dengan Kepala Desa Rawabogo, Bapak Kusnadi pada 2 Agustus 2019 pukul 10.00 WIB yang bertempat di Ruang Kerja Kepala Desa, beliau menyampaikan bahwa,

"Saya mempunyai harapan dengan adanya Desa Wisata di Desa Rawabogo ini, seluruh masyarakat dapat merasakan hasil dari usaha-usaha wisata yang ada di Desa Rawabogo ini, sehingga dapat membantu perekonomian masyarakat tentunya meningkatkan kesejahteraan masyarakat Desa Rawabogo itu sendiri." Selain itu, beliau juga menyampaikan bahwa:

Kami berharap Pokdarwis dapat merangkul seluruh warga masyarakat untuk dapat memanfaatkan Desa Wisata sebagai peluang untuk mereka menambah pendapatan sehingga dapat membantu perekonomian masyarakat, sehingga kesejahteraan masyarakat Desa Rawabogo dapat meningkat.

Sejalan dengan penyampaian Kepala Desa Rawabogo, Ketua Pokdarwis, Bapak Agung, pada kesempatan wawancara dengan beliau pada 4 Agustus 2019 pukul 13.00 WIB bertempat di kediaman beliau:
Pokdarwis diharapkan mampu menjadi wadah masyarakat untuk meningkatkan kesejahteraan melalui Desa Wisata akan tetapi belum adanya kesepahaman antara desa dan masyarakat menjadikan fungsi Pokdarwis belum maksimal karena masyarakat berpikir bahwa Pokdarwis hanya akan mengurangi jumlah pendapatannya.

Hal tersebut juga sejalan dengan harapan Pemerintah Daerah Kabupaten Bandung dalam hal ini Dinas Kebudayaan dan Pariwisata, dalam kesempatan wawancara dengan Kepala Dinas Kebudayaan dan Pariwisata Kabupaten Bandung pada 3 Agustus 2019 pukul 09.30 WIB bertempat di ruang kerja beliau,

"Disbudpar berusaha mengembangkan desa-desa di Kabupaten Bandung yang memiliki potensi, untuk membantu meningkatkan kesejahteraan masyarakat yang menonjolkan makanan, kesenian dan kebudayaan khas daerah."

Berdasarkan hasil klasifikasi beberapa strategi tersebut di atas, diketahui urutan prioritas strategi yang dibutuhkan untuk pemberdayaan masyarakat melalui Desa Wisata dalam upaya meningkatkan kesejahteraan masyarakat Desa Rawabogo. Program yang memiliki skor tertinggi adalah program Mengikuti Festival Desa Wisata yang diadakan oleh pemerintah. Program tersebut memerlukan biaya yang cukup besar dan persiapan sarana prasarana pendukung guna menampilkan stand desa wisata yang menarik. Sedangkan program yang dapat segera dilaksanakan oleh pemerintah desa adalah program penampilan kesenian dan kebudayaan Desa Rawabogo secara rutin. Hal ini ditunjukkan dengan hasil litmus test yang programprogram tersebut mendapatkan skor lebih rendah yang berarti dapat dilakukan segera agar menarik wisatawan untuk berkunjung ke Desa Wisata, maka secara tidak langsung akan membantu meningkatkan 
kesejahteraan masyarakat Desa Rawabogo dengan banyaknya wisatawan yang berkunjung ke Desa Wisata .

\section{Faktor-Faktor Penghambat Strategi Pemberdayaan Masyarakat Melalui Desa Wisata}

Berdasarkan hasil penelitian, ditemukan beberapa penghambat dalam pelaksanaan dalam upaya peningkatan kesejahteraan masyarakat melalui Desa Wisata, antara lain:

\section{- Minimnya perhatian Pemerintah Daerah}

Meskipun pariwisata menjadi salah satu prioritas dalam rencana pembangunan menengah daerah, akan tetapi realisasi yang dirasakan terutama dalam peningkatan kesejahteraan masyarakat melalui Desa Wisata belum begitu terasa khususnya terkait bantuan secara finansial. Pemerintah Daerah Disbudpar dalam hal ini masih sedikit dalam membantu masalah pendanaan, Dinas kebudayaan dan pariwisata baru bisa membantu pendanaan jika dalam even Gelar Budaya yang dilaksanakan ketika hari lahir Kabupaten Bandung. Sedangkan dalam even lain atau kegiatan lainnya justru kami berusaha untuk mencari bantuan pendanaan ke pihak lain. Seperti pengusaha pelatihanpelatihan pertanian dari Semarang.

\section{- KegiatanPendidikan danPelatihan yang tidak berkelanjutan}

Bantuan dalam bentuk pendidikan dan pelatihan yang menunjang peningkatan kesejahteraan masyarakat melalui Desa Wisata belum mampu diberikan oleh Pemerintah Daerah secara berkelanjutan. Beberapa kali pernah diselenggarakan diklat, akan tetapi tidak pernah dipantau sejauh mana pengaruh dari output dan outcome dari kegiatan diklat tersebut serta tidak diselenggarakan secara rutin sehingga tidak ada pemerataan kualitas sumber daya manusia yang ada dan cenderung tidak ada manfaat yang terasa.
Hal tersebut sejalan dengan pernyataan Kepala Desa Rawabogo, Bapak Kusnadi dalam kesempatan wawancara dengan penulis pada 2 Agustus 2019 pukul 10.00 WIB bertempat di Ruang Kepala Desa Rawabogo"

"Dalam setiap diklat yang diadakan baik oleh Disbudpar kami selalu kirimkan perwakilan masyarakat untuk mengikuti diklat tersebut, akan tetapi diklat yang diselenggarakan tidak berkelanjutan dan cenderung insidental saja."

\section{- Perbedaan persepsi tujuan pembentukan Kelompok Sadar Wisata}

Pembentukan Kelompok Sadar Wisata diharapkan mampu mengelola usaha wisata dalam rangka peningkatan kesejahteraan masyarakat melalui Desa Wisata, akan tetapi belum adanya kesamaan persepsi antara Pokdarwis dengan masyarakat dalam mengelola Desa Wisata menyebabkan sampai saat ini usaha wisata di lingkungan Desa Wisata masih berjalan secara mandiri tanpa ada campur tangan Pokdarwis, dikarenakan masyarakat berpikiran bahwa dengan dibentuknya Pokdarwis pendapatan masyarakat pelaku usaha wisata akan berkurang karena harus bagi hasil dengan Pemerintah Desa sehingga Desa Rawabogo belum dapat berkembang menjadi Desa Wisata secara utuh.

Hal tersebut dibenarkan oleh Ketua Pokdarwis, Bapak Agung dalam kesempatan wawancara dengan penulis pada 4 Agustus 2019 pukul 13.00 WIB bertempat di kediaman beliau menyatakan:

"Kami belum dapat mengumpulkan seluruh masyarakat pelaku usaha wisata dikarenakan mereka masih saja berpikiran bahwa Pokdarwis akan mengurangi jumlah pendapatan mereka karena harus ada bagi hasil antara mereka kepada Desa." 


\section{- Banyaknya investor yang menguasai lahan}

Belum adanya peraturan yang mengatur tentang mekanisme investor dalam membeli maupun menggunakan lahan di area Desa Rawabogo menyebabkan banyaknya warga masyarakat yang menjual secara mandiri kepada para investor, hal tersebut ditakutkan semakin lama akan semakin banyak pihak luar yang membuka usaha wisata dan warga masyarakat hanya akan menjadi buruh atau karyawan di tempat tersebut. Kepala Desa Rawabogo, Bapak Kusnadi dalam kesempatan wawancara dengan penulis pada 2 Agustus 2019 pukul 10.00 WIB bertempat di Ruang Kepala Desa Rawabogo menguatkan pernyataan tersebut bahwa:

Banyak masyarakat yang tergiur untuk menjual tanahnya kepada para investor untuk memenuhi kebutuhannya, hal tersebut sangat disayangkan karena Pemerintah Desa juga tidak dapat campur tangan karena sampai sekarang memang belum ada Peraturan Desa yang mengatur hal tersebut.

\section{Upaya yang Dilakukan Dalam} Menangani Faktor-faktor Penghambat Strategi Pemberdayaan Masyarakat Melalui Desa Wisata

Berdasarkan sumber daya sumber daya yang dijelaskan di atas dan hasil penelitian penulis, Pemerintah Desa Rawabogo mampu bertahan dan menghadapi segala sumber daya yang ada dengan langkah-langkah sebagai berikut.

\section{- Minimnya Perhatian Pemerintah Daerah}

Berdasarkan wawancara penulis dengan Kepala Desa Rawabogo, Bapak Kusnadi pada 2 Agustus 2019 pukul 10.00 WIB yang bertempat di Ruang Kepala Desa Rawabogo, beliau menjelaskan bahwa:
Meskipun perhatian Pemerintah Daerah masih minim, Pemerintah Desa Rawabogo tetap berjuang dalam upaya peningkatan kesejahteraan masyarakat melalui Desa Wisata menjalin kerja sama dengan pengusaha untuk peningkatan sumber daya sehingga pengusaha tersebut meminjamkan dan memberikan modal untuk kemajuan Desa Wisata tersebut.

Berdasarkan keterangan tersebut, dapat disimpulkan bahwa meskipun dukungan dari Pemerintah Daerah masih minim, akan tetapi Desa Rawabogo tetap mengusahakan dukungan-dukungan dari pihak ketiga, yaitu Pengusaha Mengadakan pelatihan bidang pertanian sebagai penyedia peminjaman modal untuk memajukan dan mewujudkan Desa Wisata.

\section{- Kegiatan Pendidikan dan Pelatihan yang tidak berkelanjutan}

Berdasarkan wawancara penulis dengan Kepala Desa Rawabogo, Bapak Kusnadi pada 2 Agustus 2019 pukul 10.00 WIB yang bertempat di Ruang Kepala Desa Rawabogo, beliau menjelaskan bahwa:

Kegiatan pendidikan dan pelatihan yang diselenggarakan oleh pihak-pihak tertentu selalu dimanfaatkan dengan baik dengan mengirimkan perwakilan masyarakat guna meningkatkan kompetensi serta mendukung dalam peningkatan kesejahteraan melalui Desa Wisata .

Berdasarkan keterangan tersebut, dapat diketahui bahwa meskipun penyelenggaraan diklat masih minim dan belum berkelanjutan, akan tetapi Desa Rawabogo selalu mengirimkan perwakilan masyarakatnya guna meningkatkan kompetensi sumber daya manusia dalam upaya peningkatan kesejahteraan masyarakat melalui Desa Wisata . 


\section{- Perbedaan Persepsi dalam pembentukan Pokdarwis}

Berdasarkan wawancara penulis dengan Ketua Pokdarwis, Bapak Agung pada 4 Agustus 2019 pukul 13.00 WIB yang bertempat di kediaman beliau:

Pokdarwis dibentuk dengan tujuan mampu mengelola seluruh pelaku usaha wisata guna meningkatkan kesejahteraan masyarakat melalui Desa Wisata, akan tetapi sebagian masyarakat pelaku usaha wisata masih ragu untuk segera mendukung tujuan tersebut dikarenakan takut pendapatannya berkurang karena harus bagi hasil dengan Pemerintah Desa. Oleh karena itu, Pokdarwis dalam menjalankan fungsinya sekarang dimulai dengan sekadar mendata jumlah pengunjung di setiap pelaku usaha wisata dan memulai mengembangkan beberapa lahan milik desa menjadi lahan untuk usaha wisata, yaitu pengembangan mata air dan lahan di persawahan yang mempunyai lokasi yang strategis untuk menikmati pemandangan perdesaan, sambil meyakinkan kepada seluruh masyarakat pelaku usaha wisata agar dapat segera bergabung dan meningkatkan kesejahteraan melalui Desa Wisata .

Berdasarkan penjelasan tersebut, dapat disimpulkan bahwa sambil meyakinkan masyarakat pelaku usaha wisata, Pokdarwis memulai langkahnya dengan mendata jumlah wisatawan yang berkunjung di setiap pelaku usaha wisata di Desa Rawabogo untuk mengetahui perkembangan daya tarik Desa Wisata dan memulai mengembangkan lahan milik desa menjadi usaha wisata, yaitu pengembangan persawahan dan juga aliran mata air pegunungan serta hamparan perkebunan yang strategis untuk menikmati suasana perdesaan.

\section{- Banyaknya Investor yang menguasai lahan}

Berdasarkan wawancara penulis dengan Kepala Desa Rawabogo, Bapak Cecep N.A Prawira pada 2 Agustus 2019 pukul 10.00 WIB yang bertempat di Ruang Kepala Desa Rawabogo, beliau menjelaskan bahwa:

Banyaknya investor yang membeli lahanlahan milik masyarakat ditakutkan semakin lama masyarakat hanya akan menjadi buruh atau karyawan di tanah sendiri, seharusnya hal tersebut dapat dicegah atau dikurangi dengan menerbitkan peraturan desa yang mengatur tentang mekanisme masuknya investor di lingkungan Desa Rawabogo.

Berdasarkan keterangan tersebut, dapat disimpulkan bahwa sebenarnya permasalahan investor yang bebas masuk dan membeli lahan di Desa Rawabogo dapat diselesaikan dengan menerbitkan peraturan desa tentang mekanisme jual beli lahan atau masuknya investor di lingkungan Desa Rawabogo, akan tetapi hal tersebut belum dapat dilaksanakan karena belum adanya inisiasi dari Pemerintah Desa sendiri. Oleh karena itu, untuk mengurangi investor masuk ke desa, Pemerintah Desa Rawabogo masih hanya sebatas menghimbau kepada masyarakat agar dapat memaksimalkan sumber daya alam yang ada untuk digunakan sebagai modal utama berusaha wisata.

\section{SIMPULAN}

Berdasarkan hasil wawancara penulis dengan informan dan tinjauan literatur yang dilakukan serta hasil analisis deskriptif dengan menggunakan analisis SWOT, maka dapat disimpulkan beberapa hal sebagai berikut.

1. Strategi pemberdayaan masyarakat yang dapat dilakukan melalui Desa Wisata dalam upaya meningkatkan 
kesejahteraan masyarakat Desa Rawabogo berdasarkan hasil analisis SWOT dan litmus tes, Strategi yang sangat strategis untuk dilaksanakan adalah Penampilan kesenian dan kebudayaan masyarakat Desa Rawabogo secara rutin; sedangkan yang kurang strategis untuk dilaksanakan saat ini, yaitu Mengikuti Festival Desa Wisata yang diadakan oleh Pemerintah;

2. Faktor-faktor penghambat strategi pemberdayaan masyarakat melalui Desa Wisata dalam upaya meningkatkan kesejahteraan masyarakat adalah:

1) Minimnya perhatian Pemerintah Daerah

2) Kegiatan Pendidikan dan Pelatihan yang tidak berkelanjutan

3) Perbedaan persepsi tujuan pembentukan Pokdarwis

4) Banyaknya investoryangmenguasai lahan

3. Upaya yang dilakukan dalam menangani faktor-faktor penghambat strategi pemberdayaan masyarakat melalui Desa Wisata dalam upaya meningkatkan kesejahteraan masyarakat adalah:

1) Mencari dukungan dari pihak ketiga, yaitu Pengusaha, Pelatihanpelatihan pertanian dan peternakan dari Dinas Pertanian dan peternakan sebagai penyedia peminjaman modal.

2) Mengirimkan perwakilan masyarakat dalam setiap kesempatan pendidikan dan pelatihan guna meningkatkan kompetensi sumber daya manusia dalam upaya peningkatan kesejahteraan masyarakat melalui Desa Wisata .
3) Menghimbau kepada masyarakat agar dapat memaksimalkan sumber daya alam yang ada dan memanfaatkan adanya Desa Wisata sebagai wadah untuk meningkatkan kesejahteraan masyarakat Desa Rawabogo sendiri dan untuk digunakan sebagai modal utama berusaha wisata.

\section{SARAN}

Berkaitan dengan simpulan di atas, maka penulis mengemukakan beberapa saran antara lain:

1. Pemerintah Kabupaten Bandung agar lebih memperhatikan dan memberikan dukungan terhadap pemberdayaan masyarakat melalui Desa Wisata dalam upaya meningkatkan kesejahteraan masyarakat Desa Rawabogo .

2. Dinas Kebudayaan dan Pariwisata dalam menyelenggarakan kegiatan pendidikan dan pelatihan agar semakin banyak sumber daya manusia yang mempunyai kompetensi dan mempercepat peningkatan kesejahteraan masyarakat dengan meningkatnya peran Desa Wisata di Desa Rawabogo . Dinas Kebudayaan dan Pariwisata agar ikut menguatkan peran Kelompok Sadar Wisata dalam meningkatkan kesejahteraan masyarakat melalui pengembangan Desa Wisata.

3. Pemerintah Desa Rawabogo agar segera membuat regulasi yang mengatur dan mendukung dalam strategi pemberdayaan masyarakat melalui Pengembangan Desa Wisata dalam upaya peningkatan kesejahteraan masyarakat Desa Rawabogo . Dan juga membantu memberikan pengertian kepada masyarakat untuk memanfaatkan 
adanya Desa Wisata sebagai lahan usaha untuk meningkatkan kesejahteraan masyarakat Desa Rawabogo.

\section{DAFTAR PUSTAKA}

A.J. Muljadi. 2009. Kepariwisataan dan Perjalanan. Jakarta: PT Raja Grafindo Persada.

Arikunto, Suharsimi. 2006. Prosedur Penelitian: Suatu Pendekatan Praktik. Jakarta: Asdi Mahasatya.

Arikunto, S. 2010. Prosedur penelitian: Suatu Pendekatan Praktik. (Edisi Revisi). Jakarta: Rineka Cipta.

Bungin, Burhan. 2009. Penelitian Kualitatif. Jakarta: Kencana.

Bryson, John M. 1999. Perencanaan Strategis Bagi Organisasi Sosial.

Arikunto, S 2008. Perencanaan Strategis Bagi Organisasi Sosial. Jakarta: Pustaka Pelajar.

Effendy, Onong Uchjana. 2008. Dinamika Komunikasi. Bandung: Remaja Rosdakarya.

Fandeli, Chafid. 2002. Perencanaan Kepariwisataan Alam. Yogyakarta: Fakultas Kehutanan Universitas Gajah Mada.

Hatten, Kenneth J dan Mary Louise Hatten. 1988. Effective

Strategic Management. Englewood Cliffs: Prentice Hall.

Hubeis, Musa dan Najib, Mukhamad. 2008. Manajemen Strategik dalam Pengembangan Daya Saing Organisasi. Bogor: PT Elex Media Komputindo.

Kartasasmita, Ginanjar. 1996. Pembangunan Untuk Rakyat: Memadukan Pertumbuhan dan Pemerataan. Jakarta: Pustaka Cidessindo.

Labolo, Muhadam. 2008. Memahami Ilmu Pemerintahan.Jakarta: Raja Grafindo Persada.
Marrus, Stephanie K.2002.Building The Strategic Plan: Find Analyze, And Present The Right Information. USA: Wiley.

Nazir, Moh. 2009. Metode Penelitian. Jakarta: Ghalia Indonesia

Rangkuti, Freddy.2006. Analisis Swot Teknik Membedah Kasus Bisnis.Jakarta: P.T. Gramedia Pustaka Utama

Sugiyono. 2014. Analisis SWOT: Teknik Membedah Kasus Bisnis. Jakarta: PT Gramedia Pustaka Utama.

Roesmidi dan Risyanti, R. 2006. Pemberdayaan Masyarakat. Bandung: Alqaprint Jatinangor.

Rasyid, M. Ryaas. 1997. Makna Pemerintahan Tinjauan Dari Segi Etika Dan Kepemimpinan. Jakarta: P.T Yarsif Watampone.

Sumaryadi, I Nyoman. 2005.Perencanaan Pembangunan Daerah Otonom dan Pemberdayaan Masyarakat. Jakarta: Citra Utama.

------------ . 2010. Sosiologi Pemerintahan, Bogor: Ghalia Indonesia.

Soekanto, Soerjono. 2006. Sosiologi Suatu Pengantar. Jakarta: PT. Raja Grafindo Persada.

Sumodiningrat, Gunawan. 1999. Pemberdayaan Masyarakat dan Jaringan Pengaman Sosial. Jakrta: PT Gramedia Pustaka Utama.

Soebagyo. 1991. Desa Wisata di Bali: Tantangan dan Kesempatan dalam Kertas Kerja PPM. Yogyakarta: UGM.

Suharto, Edi. 2014. Membangun Masyarakat MemberdayakanRakyat. Bandung: PT. Refika Aditama.

Salusu, J. 2008. Pengambilan Keputusan Stratejik. Jakarta: Grasindo.

Sugiyono. 2009. Metode Penelitian Administrasi. Bandung: Alfabeta. 
Sugiyono. 2013. Metode Penelitian Pendidikan (Pendekatan Kuantitatif, Kualitatif, dan $R \& D$.Bandung: Alfabeta.

Suharsaputra, Uhar, 2012, Metode Penelitian, Bandung: Refika Aditama.

Tjokroamindjojo, Bintoro. 1988. Teori dan Strategi Pembangunan Nasional. Jakarta: CV. Haji Mas Agung.
Wasistiono Sadu. 2003. Kapita Selekta Penyelenggaraan Pemerintah Daerah. Bandung: Fokusmedia.

- dan Simangunsong, Fernandes. 2014. Metodologi Ilmu Pemerintahan. Jatinangor: IPDN Press. 